\title{
L'oggetto corporeo. Lo spazio del corpo tra rilievo e rappresentazione
}

\author{
Marcello Balzani \\ Fabiana Raco
}

Abstract

II corpo è un luogo. Come luogo ambisce a creare spazio, memorie, significati. Ciò avviene perché non solo appaiono variazioni di genere, dimensionali, posturali, cinematiche, ma anche ogni strategia perché tali diversità si annullino o si amplifichino. II corpo è anche misura e proporzione, criterio e metodo, gradiente per correlare e descrivere lo spazio e per trasformarlo. Il potere del corpo-misura o della misura-corpo, morfotipico e standardizzato, astratto e non reale, confligge con la varietà della specie umana: sviluppo e invecchiamento, adattamento e tipicizzazione (sociale, estetica, culturale). II corpo diventa oggetto, oltre che soggetto. L'oggetto si smonta, si seziona, si trasforma. Per queste relazioni le configurazioni progettuali spaziali e oggettuali connesse al rilievo corporeo rappresentano, in architettura come nel design del prodotto, un ambito di crescente sperimentazione: ergonomia, prossemica, tecniche di user e customer centered design pongono l'individuo e i suoi caratteri morfologici, sensoriali e cognitivi al centro del progetto e dell'applicazione di tecnologie abilitanti. II rilievo corporeo e la sua selettiva e finalizzata rappresentazione definiscono da tre anni il tema didattico del Laboratorio del Disegno del primo anno del Corso di Laurea in Design del Prodotto Industriale dell'Università di Ferrara introducendo, con metodologie semplificate, alcuni elementi di ricerca e sperimentazione.

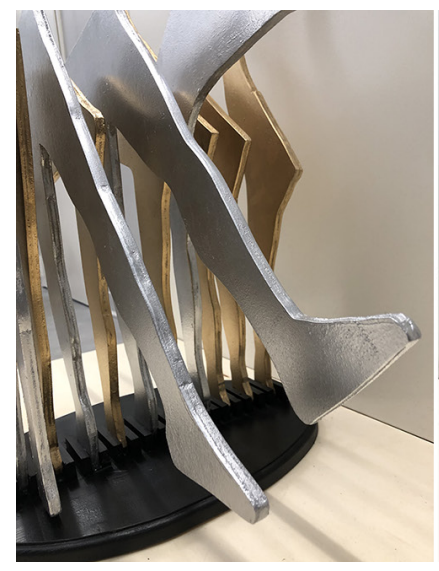

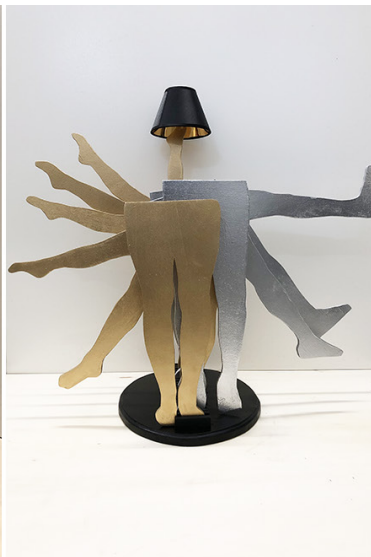

67

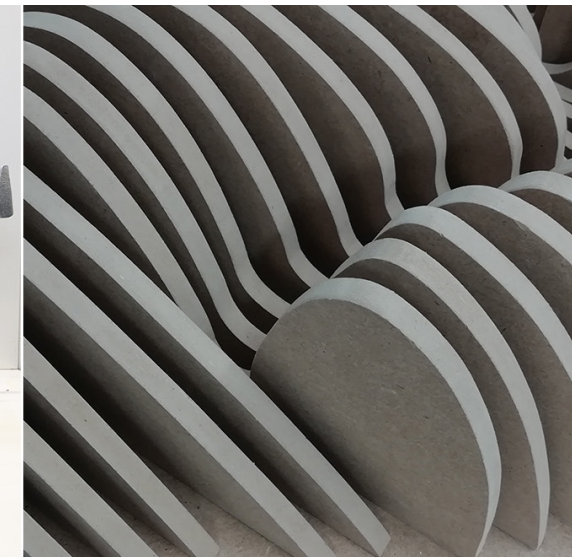

doi.org//0.3280/oa-548.5 


\section{Introduzione}

Perché il corpo? La corporeità è pervasiva, nella comunicazione a ogni livello e strumento e nel progetto, anche architettonico, che da spaziale tende a divenire sempre più oggettuale e sempre meno contestuale. II corpo torna a essere altro. II corpo nel suo essere organismo complesso, porzione microscopica o macroscopica della materia, si presenta/rappresenta da sempre come un mediatore tra codici [Lévi-Strauss 1962]: tra l'individuo e il luogo, materiale e immateriale, che egli abita; tra l'individuo e il disegno dello spazio, della città, dell'ambiente e del territorio; tra l'individuo e gli oggetti, i prodotti, le interfacce, dell'ambiente quotidiano; tra gli individui nei rapporti di relazione. II corpo che consente e condiziona la percezione dell'ambiente fisico circostante e che determina, dunque, quella complessa relazione tra l'osservatore/disegnatore e l'oggetto dell'osservazione [Muscogiuri 20 I7]. II corpo come mediatore tra l'anima e il luogo [Cardone, D'Auria, De Feo 2019]. Inversamente è possibile rintracciare nel disegno del luogo, della città, del territorio, il rapporto con il corpo, così come nel disegno e nella produzione del prodotto industriale, ora sempre più orientata alla massima personalizzazione (esclusività/inclusività, specializzazione, selettività, profilatura) è possibile leggere le forme del corpo, il gesto corporeo [Heimann 20 15], la cinestesia, nelle sue specificazioni e rapporti proporzionali e geometrici legati al genere, all'età, ma anche all'attribuzione di significati nell'ambito dei quali le componenti sensoriali, corporee e cognitive si mescolano [Hall 1988] anche con quelle posturali e cinematiche.

II disegno, il progetto e la costruzione della 'città a misura d'uomo' e di tutti gli elementi che la identificano in rapporto al corpo acquista poi, nel contesto attuale della Quarta Rivoluzione Industriale, una rilevanza inedita. La misura del corpo si fonda oggi, dalla rappresentazione (para)metrica, alle innumerevoli e diverse applicazioni dell'intelligenza artificiale e della realtà virtuale per la rappresentazione, il controllo dei livelli di maturità tecnologica e la valorizzazione del progetto, di design come di architettura, su livelli di accuratezza, di controllo delle variabili della forma e di riproducibilità tecnica, realizzabili perché sostenibili dal punto di vista della produzione.

La misura-corpo e il corpo-misura definiscono un percorso di ricerca avviato da oltre un decennio presso il centro di ricerca DIAPReM dell'Università di Ferrara (rilievo 3D e adattamento/trasformazione del 'minimo funzionale', morfotipi di produzione, ottimizzazioni posturali) e per tre anni nell'attività didattica del Laboratorio del Disegno del Corso di Laurea in Design del Prodotto Industriale.

\section{La misura del corpo e il corpo come misura}

Il percorso di indagine non può non rileggere sinteticamente come il corpo umano (o le sue membra) siano da sempre state individuate come elementi di misura e di proporzione estetica. Dal canone egiziano di Lepsius (lunghezza del dito medio della mano) al canone greco di Policleto (statua del Doriforo con la testa ottava parte dell'altezza), integrato con Vitruvio attraverso i principi di misura, simmetria e proporzione. La teoria bizantina, riportata nel Manuale del Monte Athos, resiste anche con le teorie trecentesche di Cennino Cennini e le gotiche schematizzazioni geometriche del taccuino di Villard de Honnecourt. Mentre nel Rinascimento Francesco di Giorgio Martini mantiene l'antropomorfismo vitruviano, con il flnitorium e le Tabulae Dimensionorum Hominis, Leon Battista Alberti definisce criteri di misura anticipando di quattro secoli lo studio antropometrico di Quételet, e si modifica il sistema ombelicale vitruviano a favore della base del bacino. Piero della Francesca con il De prospectiva pingendi definisce il corpo umano nel fondamento della disciplina rappresentativa e Leonardo da Vinci e Luca Pacioli (De Divina Proportione) introducono criticamente le scienze matematiche e la geometria nel modello vitruviano. Albrecht Dürer delinea con il trattato sulle proporzioni dei corpi umani (Vier Bücher von menschlicher Proportion), pubblicato postumo nel 1528 , lo studio della discretizzazione volumetrica e della simmetria, tenendo conto della variabilità della statura e della morfometria. Ma solo nel XVII secolo con Antropometria, sive De mutua membrorum corporis humani proportione, pubblicato nel 1663, Johann Sigi- 


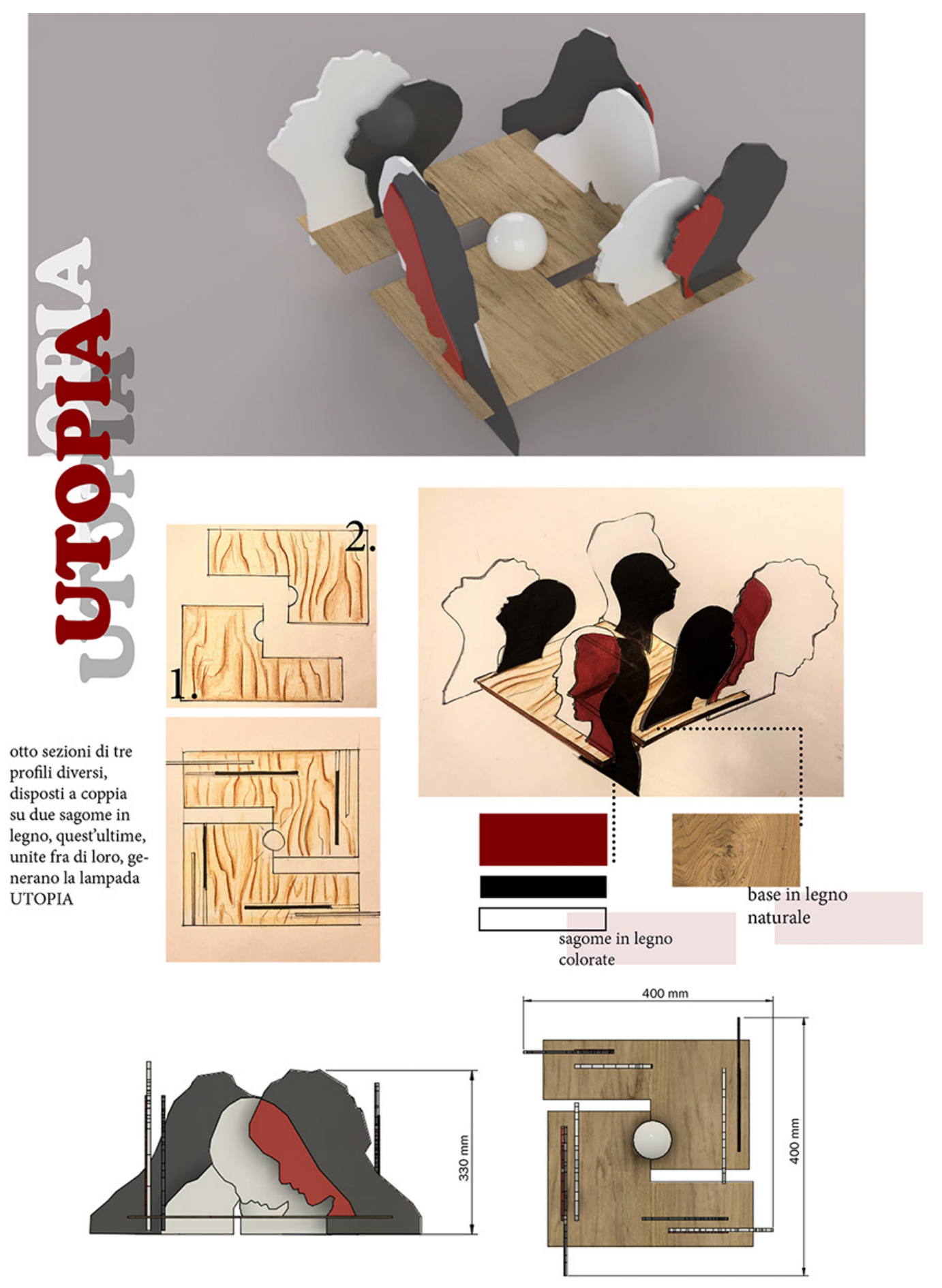


smund Elsholtz getta le basi di questa disciplina, che Adolphe Quételet in La physique sociale del I 869 rende una scienza, delineando per la prima volta il modello statistico dell'uomo medio, che si basa sullo sviluppo dell'ideologia delle razze, progressivamente elaborata da Linneo, Buffon e White già dalla fine del XVIII secolo. Per gli indici antropometrici bisogna attendere lo svedese Anders Adolf Retzius con il suo studio di antropologia fisica. E mentre nel XX secolo Le Corbusier inventa il suo nuovo Modulor, con la Bauhaus e il Movimento Moderno si costituisce la struttura del minimo funzionale, portando negli anni ad adottare la teoria del percentile e importanti quanto necessarie applicazioni ergonomiche. Poi, dal secondo dopoguerra, l'industrializzazione dei processi produttivi dei prodotti di abbigliamento e di arredo da un lato, e l'avvento del consumismo dall'altro trasformano progressivamente la percezione dei modelli a favore di rapporti sproporzionati (donna fashion) e sempre più deformati, mentre, a compensazione, dalla metà degli anni Ottanta con l'Universal Design e il Design for All aumenta la consapevolezza di una progettazione accessibile e inclusiva che faccia riferimento a diversi profili di utenza.
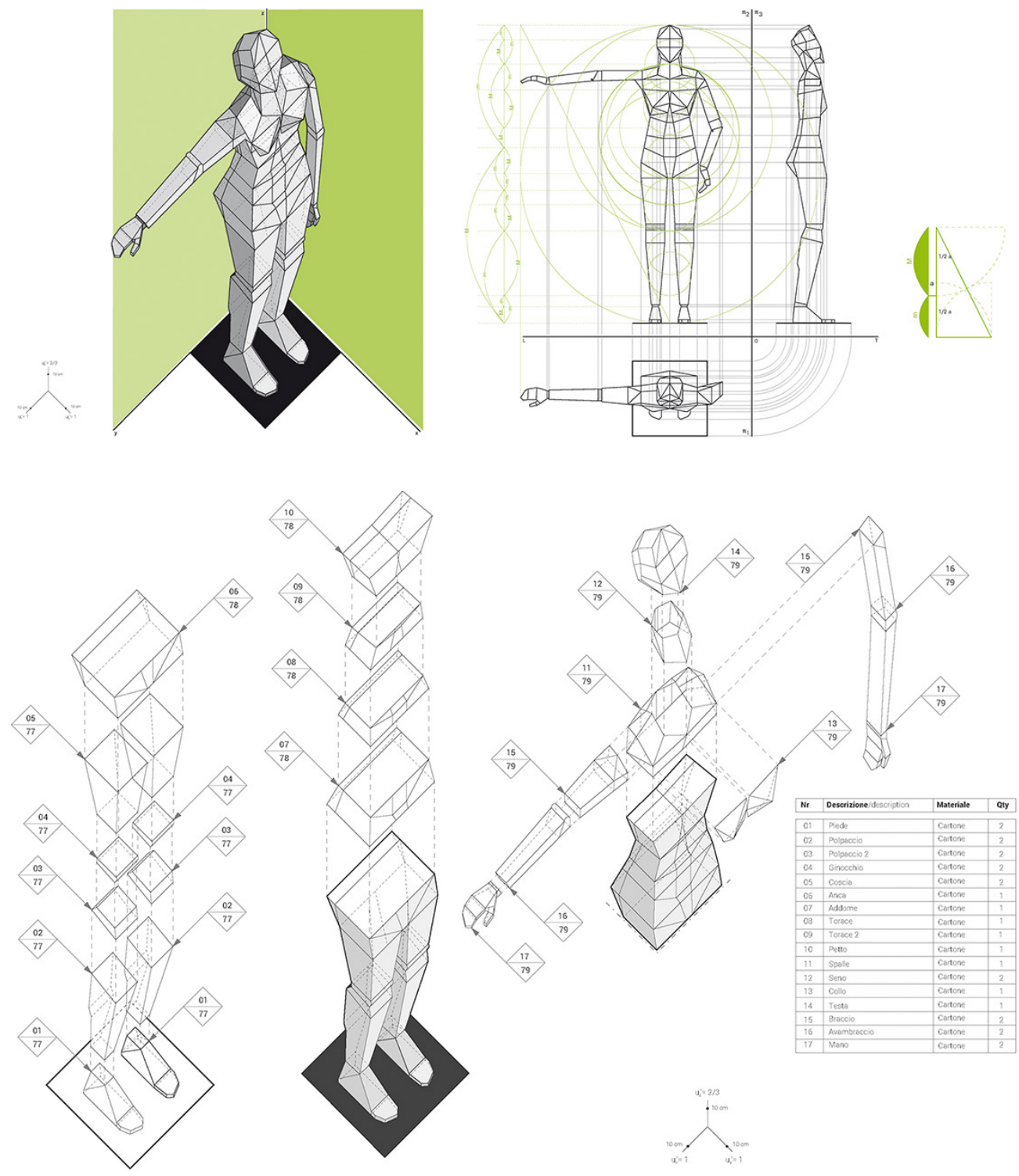
Fig. 3. Composizione delle sezioni corporee (studen Carlino, a.a. 2018-2019)

Fig. 4. Reverse engineering per la rappresentazione e assemblaggio dei
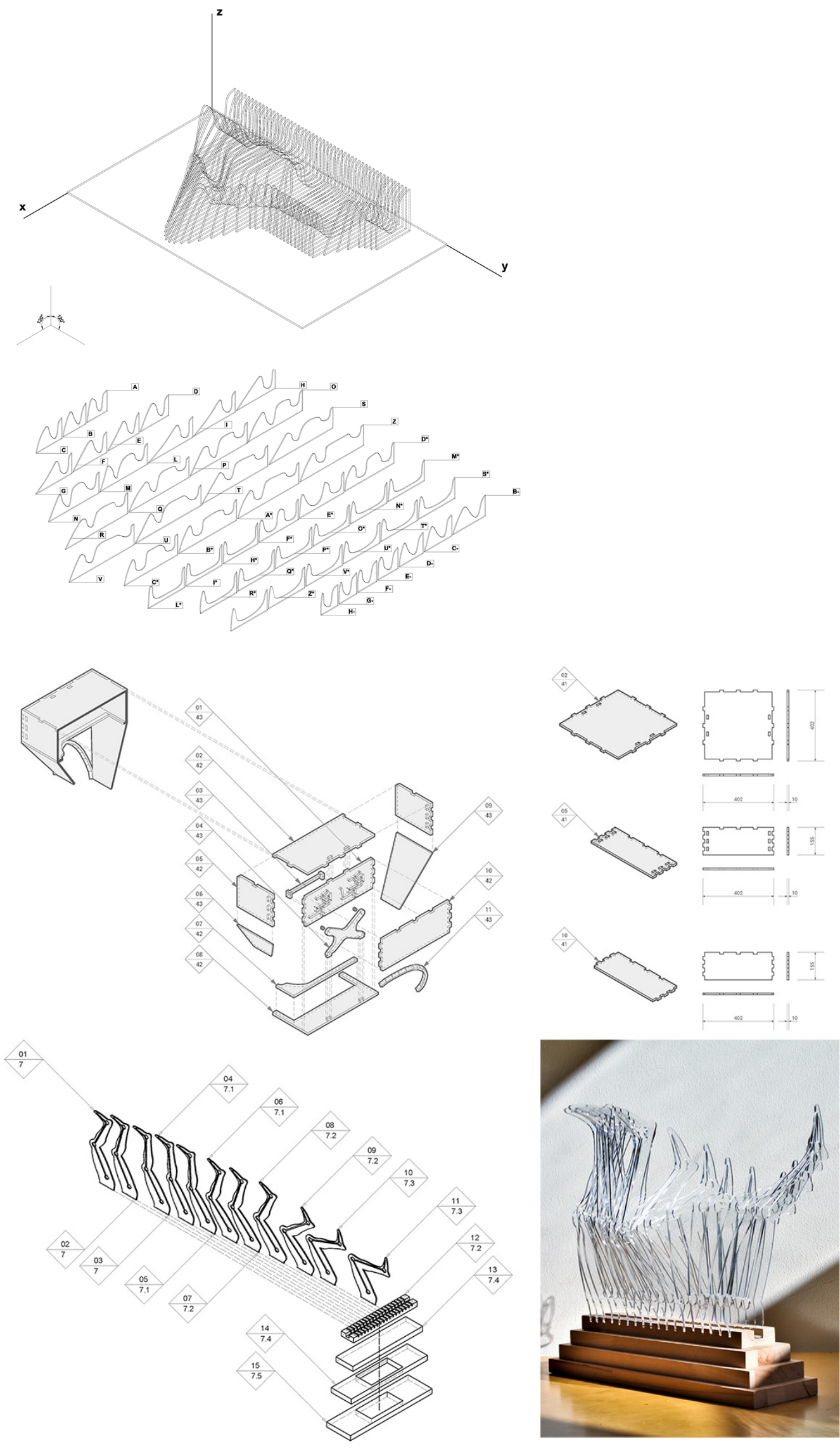


\section{Dal rilievo alla rappresentazione discretizzata del corpo-oggetto}

A fini della sperimentazione didattica e di ricerca il primo oggetto di indagine è il proprio corpo. Riconoscersi attraverso diverse chiavi di lettura. Ad esempio, le proporzioni: capire come ogni variazione dimensionale è proporzionata. Attraverso la suddivisione vitruviana in 8/8 (nell'ambito della quale la testa rappresenta I/8, collo e torace 3/8 e bacino e gambe 4/8) gli studenti sono stati chiamati a indagare criticamente innanzitutto i rapporti proporzionali del proprio corpo, comparandolo poi con quello del compagno/a, soprattutto per confronto di genere. Per poi passare a indagare gli aspetti antropometrici e posturali. Dal punto di vista sia della ricerca sia della formazione del futuro designer si sottende a una duplice finalità. Da un lato si affronta fin da subito lo studio delle specificità proporzionali della figura umana per poi desumerne, secondo un approccio di reverse engineering, le regole di variazione della morfologia. Dall'altro si introducono, attraverso un modello gerarchizzato e selettivo, i concetti di variazione della forma in relazione a:

- differenze di genere in ottica di crescita (bambino/a, adulto, anziano/a); relazioni ergonomiche; - differenze morfologiche in rapporto allo spazio (corpo-spazio, corpo-oggetti, corpo-arredi); - differenze morfologiche in rapporto alle differenze posturali (catena posturale) e alla cinesica/dinamica (movimento arti, flessibilità, torsioni).

Fig. 5. Studio dell'ambito corporeo di riferimento (studentessa: Barbara Mantovani, a.a. 2017 -

2018).
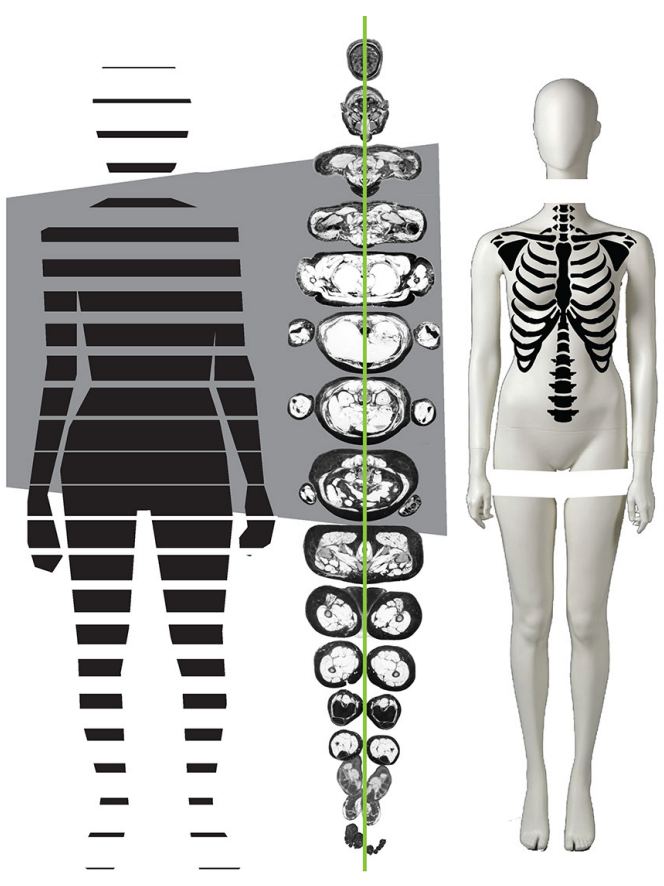

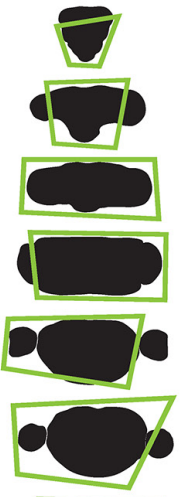

SEZIONATO COMPOONENTI DELLA GABBIA

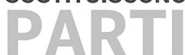

DEL BUSTO

SPEZZANDOLO
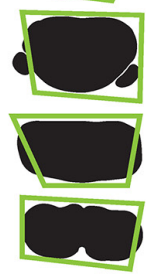

Per procedere nel percorso di indagine è stato proposto agli studenti un 'protocollo di ricerca' che prende avvio dalla individuazione di piani e assi passanti da punti noti, come le 'cerniere' corrispondenti alle articolazioni (con relative 'catene' posturali), esaminando dapprima l'orientamento spaziale principale della struttura corporea: postura eretta e la giacitura simmetrica. Tre sono stati i piani di riferimento adottati: piano frontale, per l'analisi dell'altezza nella profondità; piano sagittale o mediano, per lo studio della larghezza nell'altezza; piano trasversale, per lo studio della larghezza nella profondità. La successiva traslazione (utilizzando cerniere e catene della struttura) dei piani di riferimento per l'individuazione delle 'sezioni corporee' rappresentative è stata oggetto dello studio degli studenti che, suddivisi in gruppi, hanno affrontato il rilievo e il disegno discretizzato delle sezioni corporee in relazione a un tema di 
progetto di oggetto-corporeo individuato. II tema richiedeva di definire:

- ambito corporeo: viso/testa/volto, collo/spalle, avambracci/mani, busto, arti inferiori gamba/ piedi;

- differenze: di genere, antropometriche, posturali;

- movimento: interazioni dinamiche e cinesiche (azioni come sedersi, appoggiarsi a un muro, superare un ostacolo o in rapporto a specifiche attività funzionali, lavorative o sportive).

Individuato l'ambito, applicando il protocollo nella investigazione delle variazioni e differenze rispetto ai piani di riferimento, si individuano (e poi rilevano e rappresentano) sezioni corporee definite, elaborate secondo la postura, il movimento e l'ingombro spaziale dei diversi corpi.
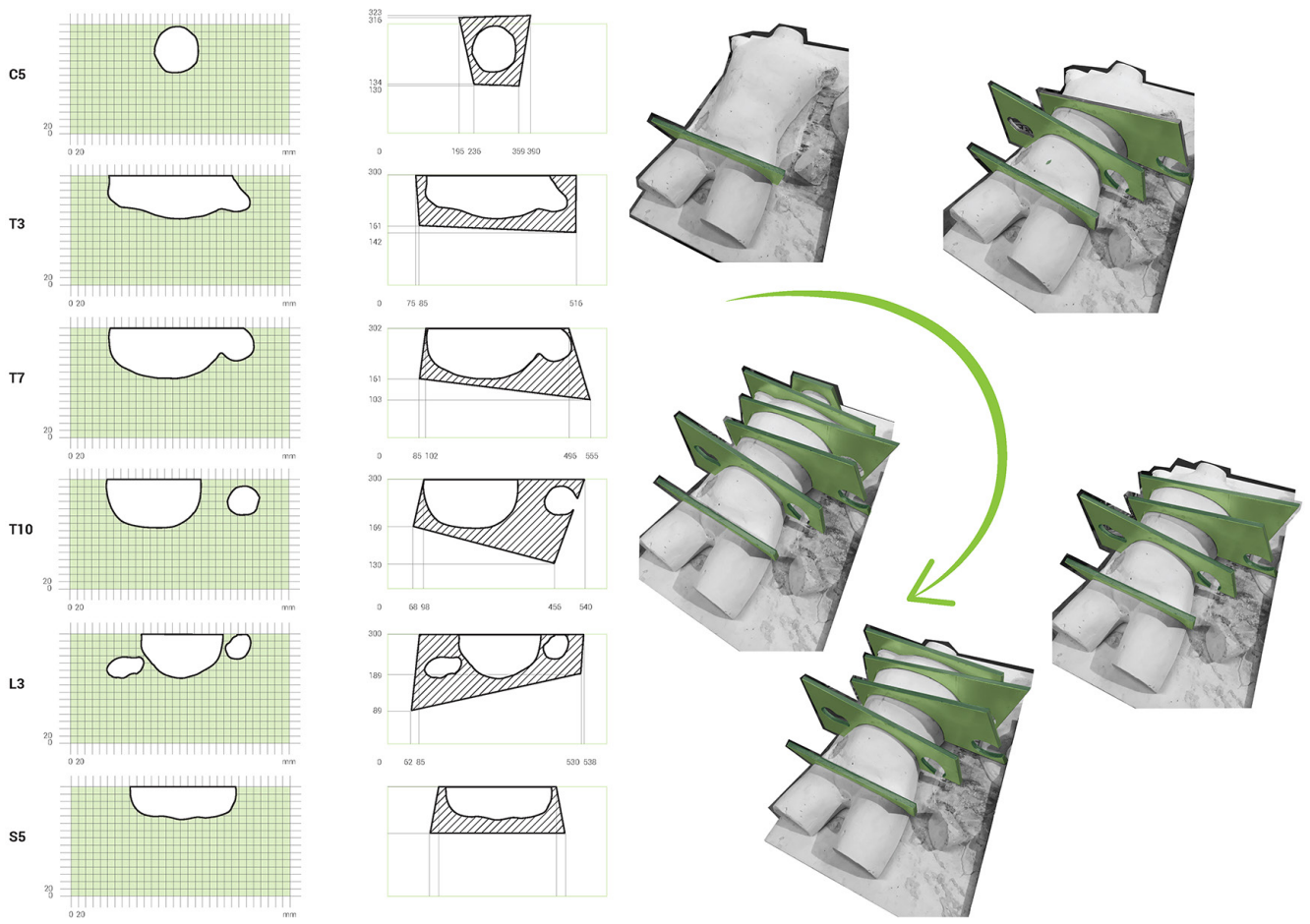

\section{Dall'indagine a confronto dei corpi all'oggetto-corporeo}

Il confronto tra i propri corpi avviene in due momenti:

- il primo si sviluppa nella definizione di una 'proporzione complessiva' realizzando un volume circoscritto discretizzato di tutto il corpo per ogni soggetto. Ė un"armatura corporea' necessaria a comprendere, attraverso forme semplici, le principali diversità e variazioni morfologiche e dimensionali tra i soggetti del gruppo;

- il secondo, scelto l'ambito corporeo, si concentra con un approccio antropometrico alla definizione di una serie di indicatori metaprogettuali utilizzati tanto nelle successive scelte rappresentative delle sezioni corporee, quanto nella composizione dell'oggetto finale.

Le dimensioni di altezza, lunghezza e larghezza vengono misurate tra punti di riferimento antropometrici e allo stesso modo la traslazione dei piani di sezione avviene con riferimento ai medesimi punti noti, al fine di misurare le differenze di genere, antropometriche e posturali, acquisite nel raffronto tra elementi, ambiti corporei, omologhi. Nelle azioni di rilievo si utilizzano tecniche fotografiche su fondali centimetrici, profilature a contatto in cartone e il metodo delle coordinate ortogonali.

In tal senso vengono quindi introdotti nel processo di rilievo, comprensione, rappresentazione e sviluppo della forma i concetti dell'ergonomia e della prossemica. Non solo dunque lo studio del rapporto tra individuo e individui, tra spazio e oggetti nella direzione dell'otti- 
mizzazione della forma correlata alle capacità e limiti psicofisiologici dell'uomo, ma anche dei significati associati al comportamento/azione/postura e al modo dell'individuo di porsi nello spazio e di organizzarlo, sia in senso fisico sia che figurato. II processo di sviluppo formale dell'oggetto corporeo attraversa cinque fasi fondamentali:

- il disegno dell'idea, elaborato attraverso la tecnica del concept sketching;

- il rimando a riferimenti significativi nell'arte, nelle comunicazioni visive, nel cinema, nella letteratura, nella musica;

- la relazione con un sentimento/emozione: attribuendo all'oggetto-corporeo uno o più affetti e/o pulsioni specifiche, non in senso generico o personale, ma utilizzando le categorie emotive scandagliate dalla filosofa ungherese Ágnes Heller nel suo celebre trattato sulla Teoria dei sentimenti [Heller 20 I7]; un vincolo importante per mantenere la ricerca sul corpo all'interno di un ambito di significato non solo di tipo geometrico-formale;

- il riferimento a una tipologia di variazione cinesica/dinamica;

- l'oggettivazione (consumistica, violenza di genere, esclusività/inclusività) è una variante ammessa solo in alcuni casi, ma necessaria per comprendere il percorso di lettura critica in ambito sociale che giocare col proprio corpo determina.

A seconda dei casi sono ammesse scalabilità formali per articolare gli oggetti. Dall'abaco dei componenti corporei (sezioni estratte) si realizzano:

- oggetti che strutturano la relazione corporea attraverso un contatto fisico col proprio corpo: forme aderenti al corpo (abito-abitabili) che vincolano morfologicamente l'ambito corporeo selezionato a una specifica condizione geometrico-formale;

- oggetti di arredo, come lampade, tavoli, mensole, che sono espressioni della relazione corporea generata dall'assemblaggio delle sezioni; vengono messe in evidenza le motivazioni selezionate come fondamentali nell'applicazione del protocollo di indagine.
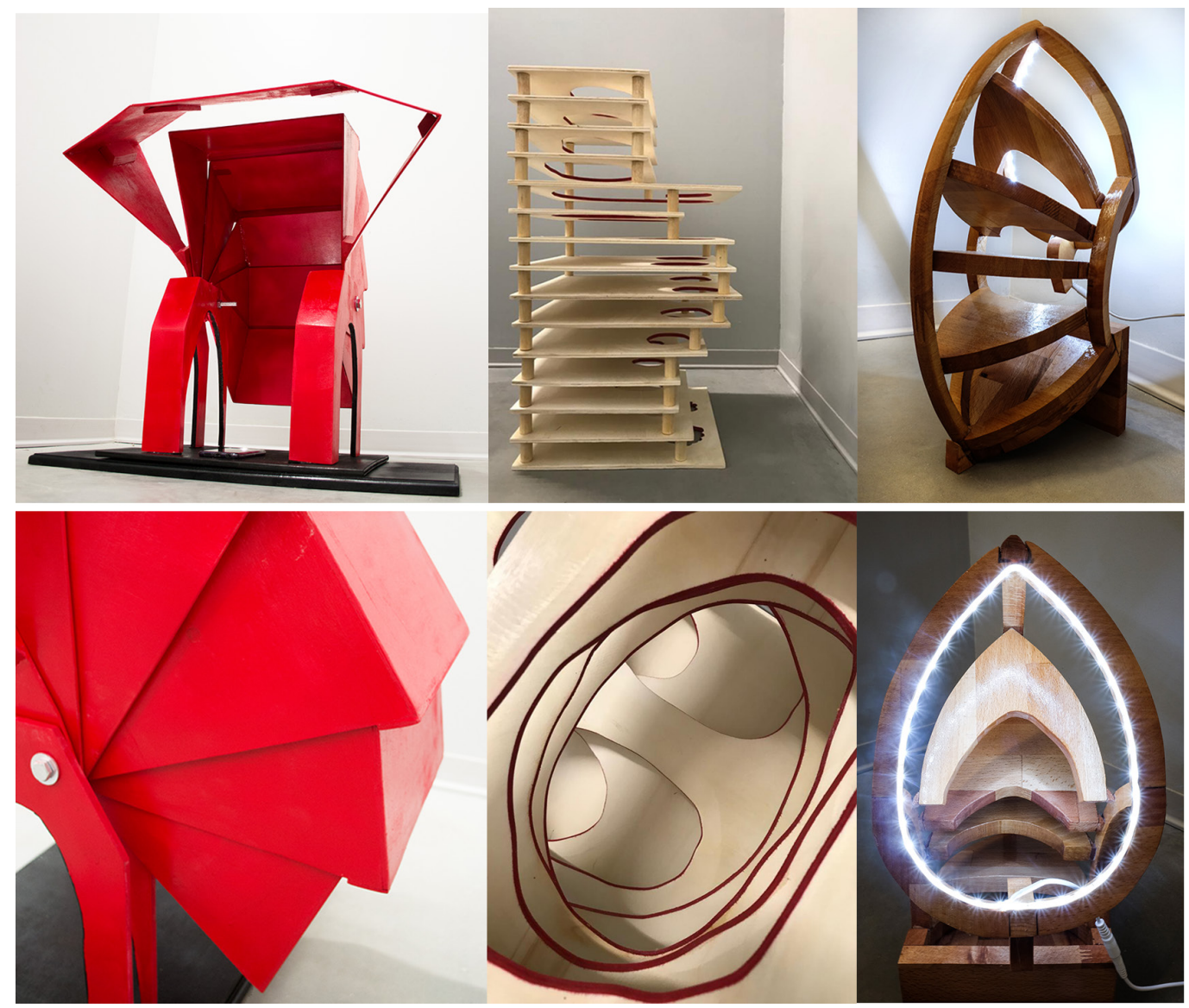
Il processo di sviluppo applicato realizza prima uno o due prototipi e poi un modello fisico in laboratorio con materiali solidi (come legno e plexiglas), dal quale, con l'approccio di reverse engineering, si torna a rilevare e rappresentare l'abaco finale e l'assemblaggio dei componenti in esploso assonometrico.

\section{Conclusioni}

La ricerca sulla dimensione corporea e su come la risultante spaziale possa essere generata sia dal contesto geometrico dello spazio o viceversa possa essere determinata dalla sommatoria di tutte le interazioni corporee (funzionali, energetiche, posturali, prossemiche, emozionali) in un inviluppo spaziale che ne definisce la forma apparente è ancora da completarsi. È evidente come l'interesse per l'insita relazione conflittuale (tra soggetto umano e ambiente confinato o meno) apra ambiti di investigazione di grande interesse su molti versanti interdisciplinari. L'oggetto corporeo è in fondo un ossimoro nella materializzazione di quel significante fluttuante tanto caro a Lévi-Strauss, che rendeva il corpo un potente mediatore tra codici (oggi diremmo domini) facendo leva non solo sul pensiero scientifico ma anche su quello simbolico. Forse il percorso definito (e qui sinteticamente presentato) costituisce un utile caso studio di una destrutturata [Deridda 20 19] combinazione di elementi, che può, anche sul piano del risultato oggettuale costruire famiglie di appartenenza, insieme oggettuali di diversa natura d'origine, di una nuova zoologia formale che non perda di vista la tradizione e i metodi di rilievo e rappresentazione. Si può intuire la messa a punto di un protocollo sull'oggetto corporeo, che viene migliorato durante le sperimentazioni didattiche. È un primo risultato di ricerca ottenuto con tutte le autorizzazioni (connesse all'utilizzo di dati sensibili e personali) da parte dei soggetti interessati a essere contemporaneamente investigatori e cavie del proprio corpo.

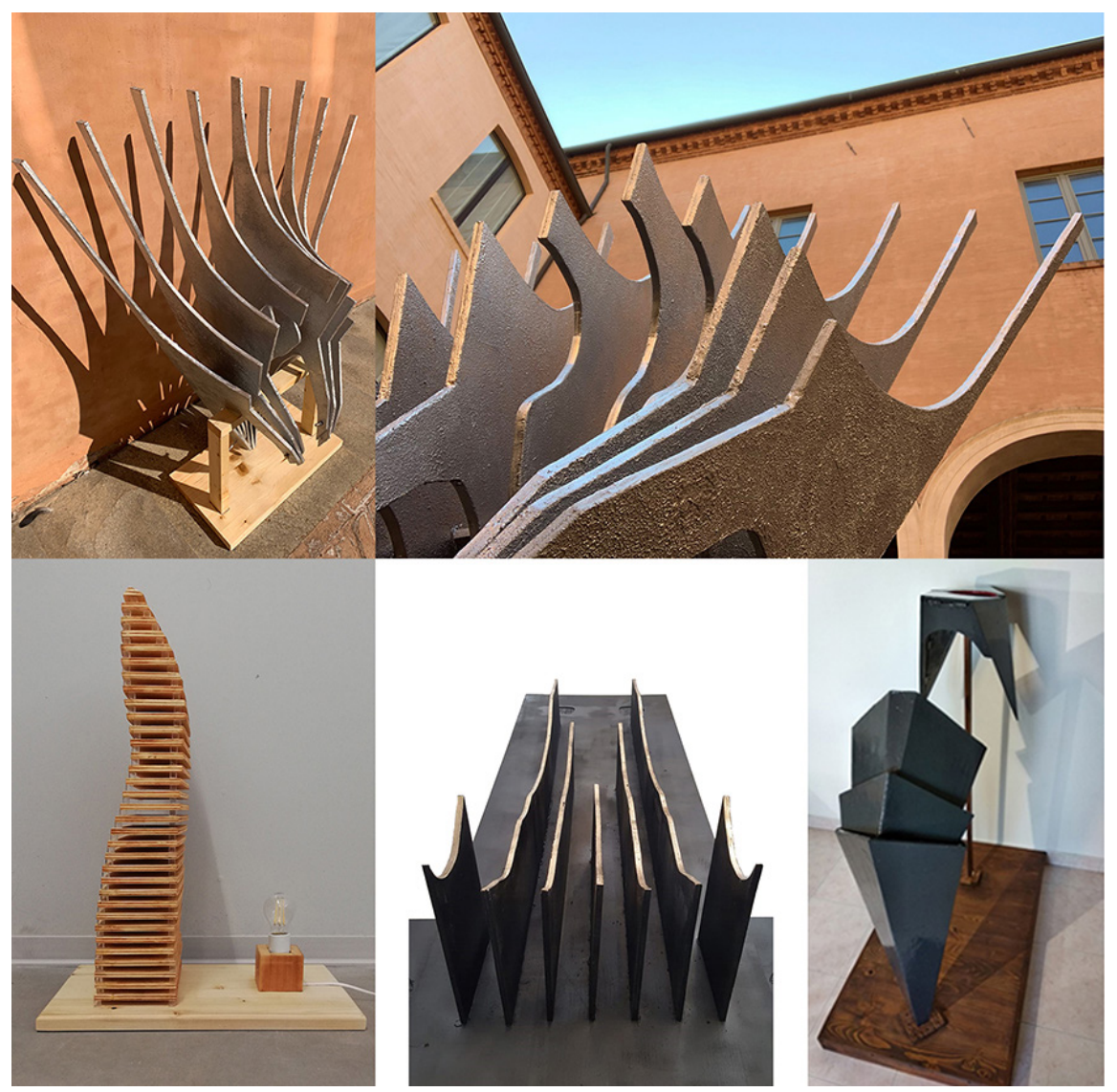




\section{Riferimenti bibliografici}

Adler David (2002). Manuale di dati e misure per la progettazione. Torino: Utet.

Argyle Michael (1978). Il corpo e il suo linguaggio. Bologna: Zanichelli.

Balzani Marcello et al. (2009). O3D The breaking down of the motion. The corporeal dynamism and the morphometric structures by 3D laser scanner survey. Optical 3-D Measurement Techniques IX. In AA.W. Atti del 9th Conference on Optical 3-D Measurement Techniques Optical 3-D Measurement Techniques IX.Vienna: Druckerei Janetschek, vol. I, pp. 299-305.

Boni Stefano (2014). Homo comfort. Il superamento tecnologico della fatica e le sue conseguenze. Milano: Elèuthera.

Cardone Vitale, D'Auria Saverio, De Feo Emanuela (2019). Literary and travel images for the knowledge of the city. In Janeiro Pedro António (a cura di). Atti del 5th International Seminar Architectural, Representation and other Images Drawing (...) City (...) Body, Dwelling on Earth: Imagined-Architectures: Architectural Graphic Representation and Other Images. São Paulo (Brazil), 5-9 marzo 2019, pp. 203-212. London: CRC Press, Taylor \&Francis Ltd.

Derrida Jaques (2019). Toccare, Jean-Luc Nancy. Bologna: Marietti.

Galimberti Umberto (2002). II corpo. Milano: Feltrinelli.

Gourhan André Leroi (1977). Il gesto e la parola. Tecnica e linguaggio. La memoria e i ritmi. Roma: Einaudi.

Hall Edward T. (1988). La dimensione nascosta: il significato delle distanze tra i soggetti umani. Milano: Bompiani.

Heller Agnes (2017). Teoria dei sentimenti. Roma: Castelvecchi.

Le Corbusier (1949). II modulor. Saggio su una misura armonica su scala umana universalmente applicabile all'architettura e alla meccanica. (trad. it. 1974). Milano: Mazzotta editore.

Lévi-Strauss (1962). Il totemismo oggi. Milano: Feltrinelli. (Edizione italiana 1964).

Muscogiuri Marco (2017). Disegno dal vero, urban sketching e fenomenologia della percezione. In di Luggo Antonella et al. (a cura di). Territori e frontiere della rappresentazione. Atti del $39^{\circ}$ Convegno Internazionale dei Docenti delle Discipline della Rappresentazione. Napoli, I4- 16 settembre 2017, pp. 725-732. Roma: Gangemi.

Panero Julius e Zelnik Martin (1989). Spazi a misura d'uomo: manuale delle misure utili alla progettazione. Milano: Be-Ma.

Panofsky Erwin (2010). II significato nelle arti visive. Torino: Einaudi.

Sicklinger Andreas (2009). Ergonomia applicata al progetto. Cenni Storici e Antropometria. Santarcangelo di Romagna: Maggioli Editore.

Autori

Marcello Balzani, Università degli Studi di Ferrara, bzm@unife.it

Fabiana Raco, Università degli Studi di Ferrara, rcafbn@unife.it

Per citare questo capitolo: Balzani Marcello, Raco Fabiana (2020). L'oggetto corporeo. Lo spazio del corpo tra rilievo e rappresentazione/Object towards human body. The space of human body between the surveying and representation processes. In Arena A., Arena M., Brandolino R.G. Colistra D., Ginex G., Mediati D., Nucifora S., Raffa P. (a cura di). Connettere. Un disegno per annodare e tessere. Atti del $42^{\circ}$ Convegno Internazionale dei Docenti delle Discipline della Rappresentazione/Connecting. Drawing for weaving relationships. Proceedings of the 42th International Conference of Representation Disciplines Teachers. Milano: FrancoAngeli, pp. 67-86. 


\title{
Object towards Human Body. The Space of Human Body between the Surveying and Representation Processes
}

\author{
Marcello Balzani \\ Fabiana Raco
}

Abstract

The human body is a place. As a place it aspires to create space, memories, meanings. This happens not only because of the changes about gender, dimension, posture, kinematics appear, but also because differences became design strategies to be cancelled or amplified. The human body is also measure and proportion, project criterion and method and describe space and the way to transform it. The human body-measure or measuring based on human body contrasts, morpho-typical and standardized, abstract and not real, with the variety of the human species: aging, adaptation and typification (social, aesthetic, cultural). The human body becomes object, as well as subject. The object is disassembled, dissected, transformed. Definitely, the spatial and object design configurations connected to the survey of human body represent, in architecture as well as in product design, an area of growing experimentation: ergonomics, proxemics, user and customer centered design techniques position the individual and his morphological, sensory and cognitive characters at the center of the project and the application of key enabling technologies. The survey of human body and its finalized representation have been defining for three years the didactic theme of the Design Laboratory of the first year of the degree course in Industrial Product Design at the University of Ferrara, introducing, with simplified methodologies, some elements of research and experimentation.

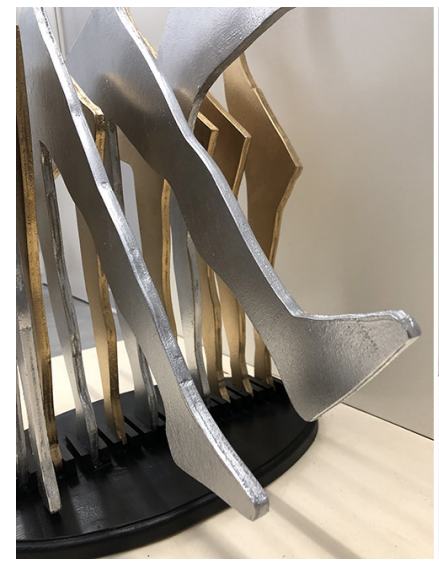

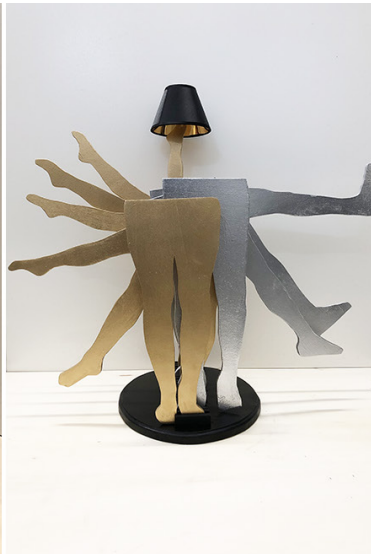

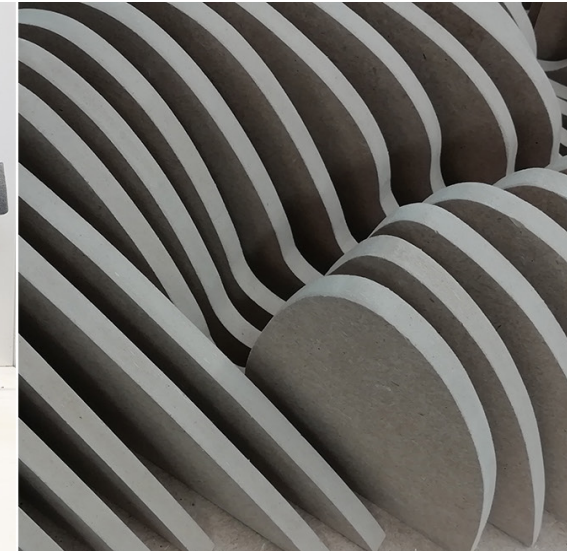

doi.org//0.3280/oa-548.5 


\section{Introduction}

Why the human body? The quality of having a physical or material body is pervasive, in communication at every level and in the project as a tool, even architectural project, which leads to become even more objective and less contextual. The human body becomes something else again. The human body in its being a complex organism, microscopic or macroscopic portion of the matter, has always been presented/represented as a medium between codes [Lévi-Strauss 1964]: between the individual and the place, both material and immaterial, that he inhabits; between the individual and the design of space, city, environment and territory; between the individual and objects, products, interfaces, everyday environment; within the relation between individuals. The human body defines the perception of the surrounding physical environment and determines, therefore, the complex relationship between the observer/designer and the object of observation [Muscogiuri 2017]. The human body as a medium between soul and place [Cardone, D'Auria, De Feo 2018]. Definitely, it is possible to put in evidence in the design of a place, the city, the territory, the relation with the human body, as well as in the product design, which is now increasingly oriented towards maximum customization (exclusivity/inclusiveness, specialization, selectivity, profiling), it is possible to trace the forms of the human body, the bodily gesture [Heimann 20 I 5]. Kinesthesia is mixed with the postural and kinematic components so that the geometric aspects related to gender, age and the attribution of meanings, the perceptions and the cognitive components [Hall I 988] are mixed.

The design, the project and the construction of the human scale city and of all the elements that identify its relation to the human body acquire a previously unknown importance in the context of the Fourth Industrial Revolution. Definitely, the measure of the human body is based, from the (para)metric representation to the several applications of artificial intelligence and virtual reality for the representation, the control of the technology readiness level and the project exploitation, on new levels of accuracy within a sustainable production process.

The measurement of human body and the human-based measures define a research path started more than a decade ago at the DIAPReM research centre of the University of Ferrara (3D survey and adaptation/transformation of the minimum requirements, human body morphotypes, postural optimizations) and three years ago in the didactic activity of the Design Laboratory the in Industrial Product Design degree course.

\section{The measure of the human body and the human body-based measure}

The path of investigation cannot but reread synthetically how the human body have always been identified as elements of measurement and aesthetic proportion. From the Egyptian Canon of Lepsius (length of the middle finger of the hand) to the Greek Canon of Polycletus (statue of Doriforo with the head eighth part of the height), integrated with Vitruvius through the principles of measurement, symmetry and proportion. The Byzantine theory, reported in the Manual of Mount Athos, also resists with the fourteenth-century theories of Cennino Cennini and the Gothic geometrical schematizations of Villard de Honnecourt's notebook. While in the Renaissance Francesco di Giorgio Martini maintained Vitruvian anthropomorphism, with the Finitorium and the Tabulae Dimensionorum Hominis, Leon Battista Alberti defined measurement criteria anticipating the anthropometric study of Quételet by four centuries, and modified the Vitruvian umbilical cord system in favour of the base of the basin. Piero della Francesca with the De prospectiva pingendi defines the human body in the foundation of the representative discipline and Leonardo da Vinci and Luca Pacioli (De Divina Proportione) critically introduced mathematical sciences and geometry in the Vitruvian model. Albrecht Dürer outlined with his treatise on the proportions of human bodies (Vier Bücher von menschlicher Proportion), published posthumously in I528, the study of volumetric discretization and symmetry, taking into account the variability of stature and morphometry. But it was only in the 17th century with Anthropometria, sive De mutua 


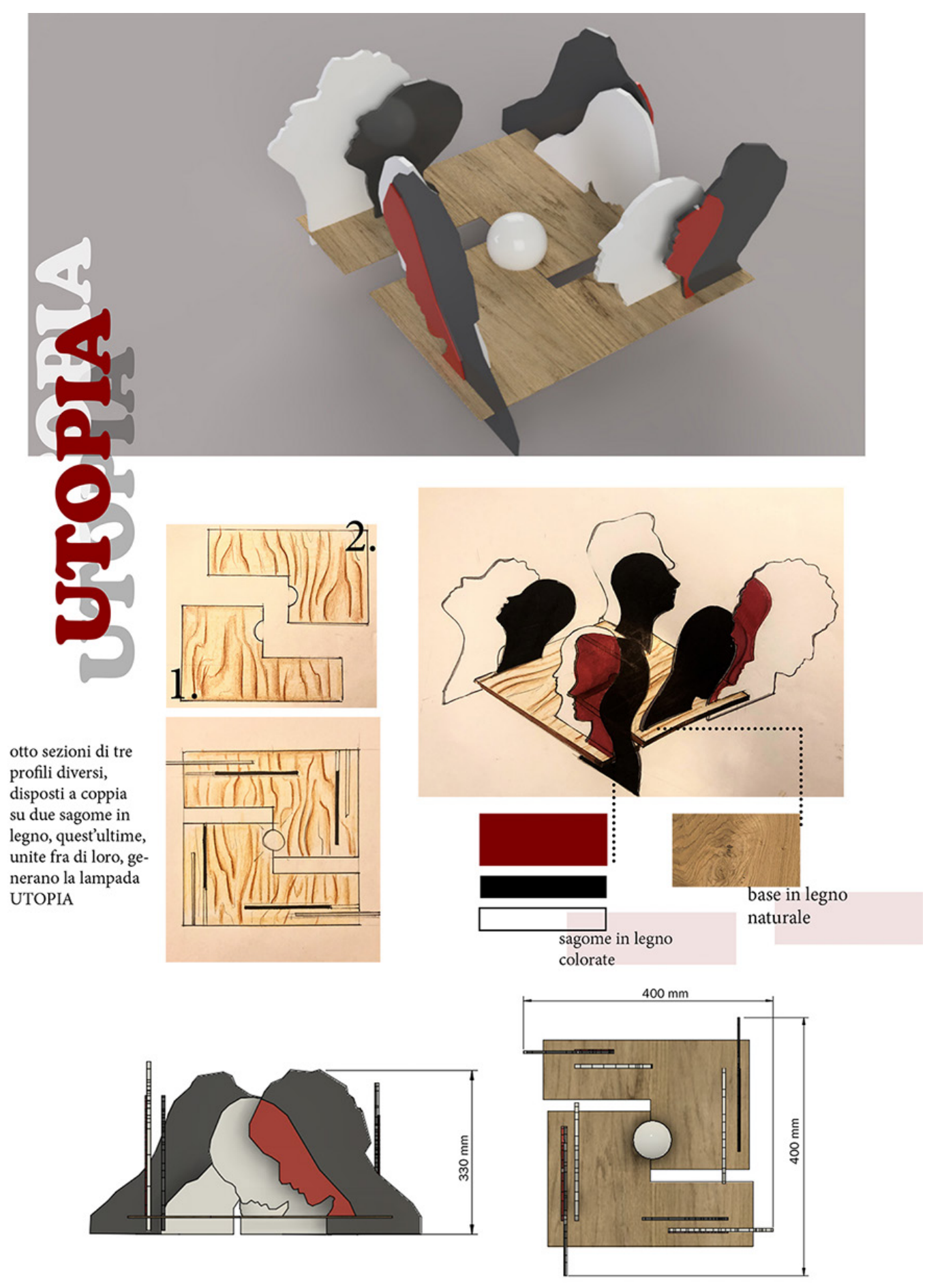


membrorum corporis humani proportione, published in 1663, that Johann Sigismund Elsholtz laid the foundations of this discipline, which Adolphe Quételet in La physique sociale of 1869 made a science, outlining for the first time the statistical model of the average man, based on the development of the ideology of races, progressively elaborated by Linnaeus, Buffon and White since the end of the 18th century. For the anthropometric indixes we have to wait for the Swedish Anders Adolf Retzius with his study of physical anthropology. And while in the 20th century Le Corbusier invented his new Modulor, with the Bauhaus and the Modern Movement the structure of the functional minimum was established, leading over the years to adopt the theory of the percentile and important as well as necessary ergonomic applications. Then after the Second World War, the industrialization of the production processes of clothing and furniture products on the one hand, and the advent of consumerism on the other, progressively transformed the perception of models in favour of disproportionate ('fashionable women') and increasingly deformed relation, while since the mid-1980s with Universal Design and Design for All increasing the awareness of an accessible and inclusive design that refers to different user profiles.
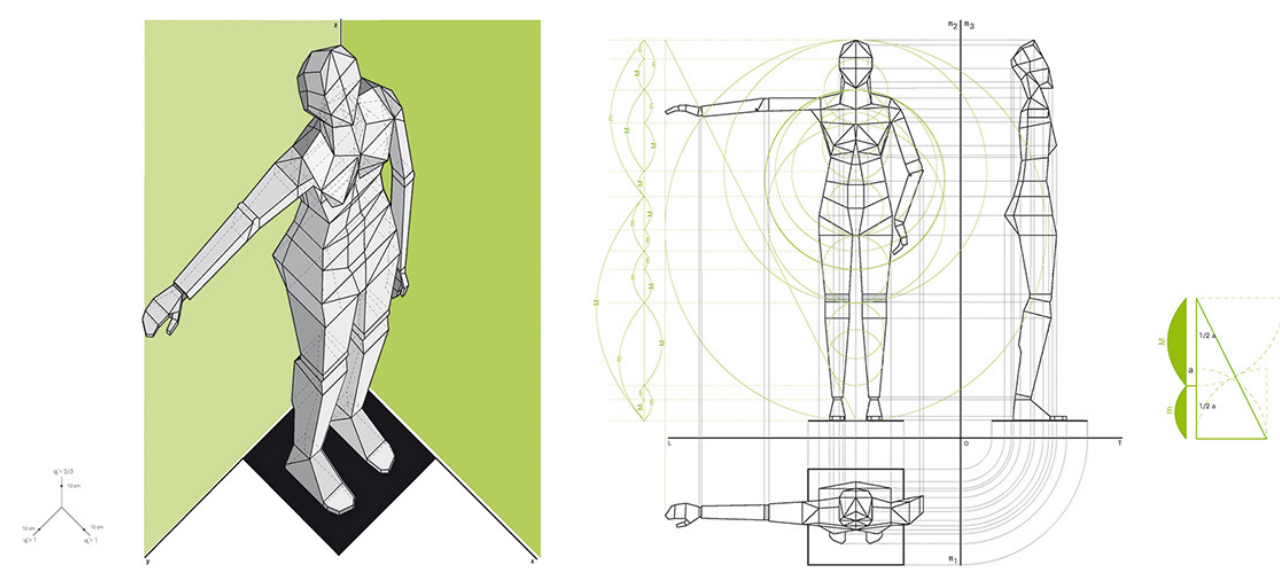

Fig. 2. From the survey to discrete representation of the human body (student: Barbara Mantovani, a.y. 2017-2018).
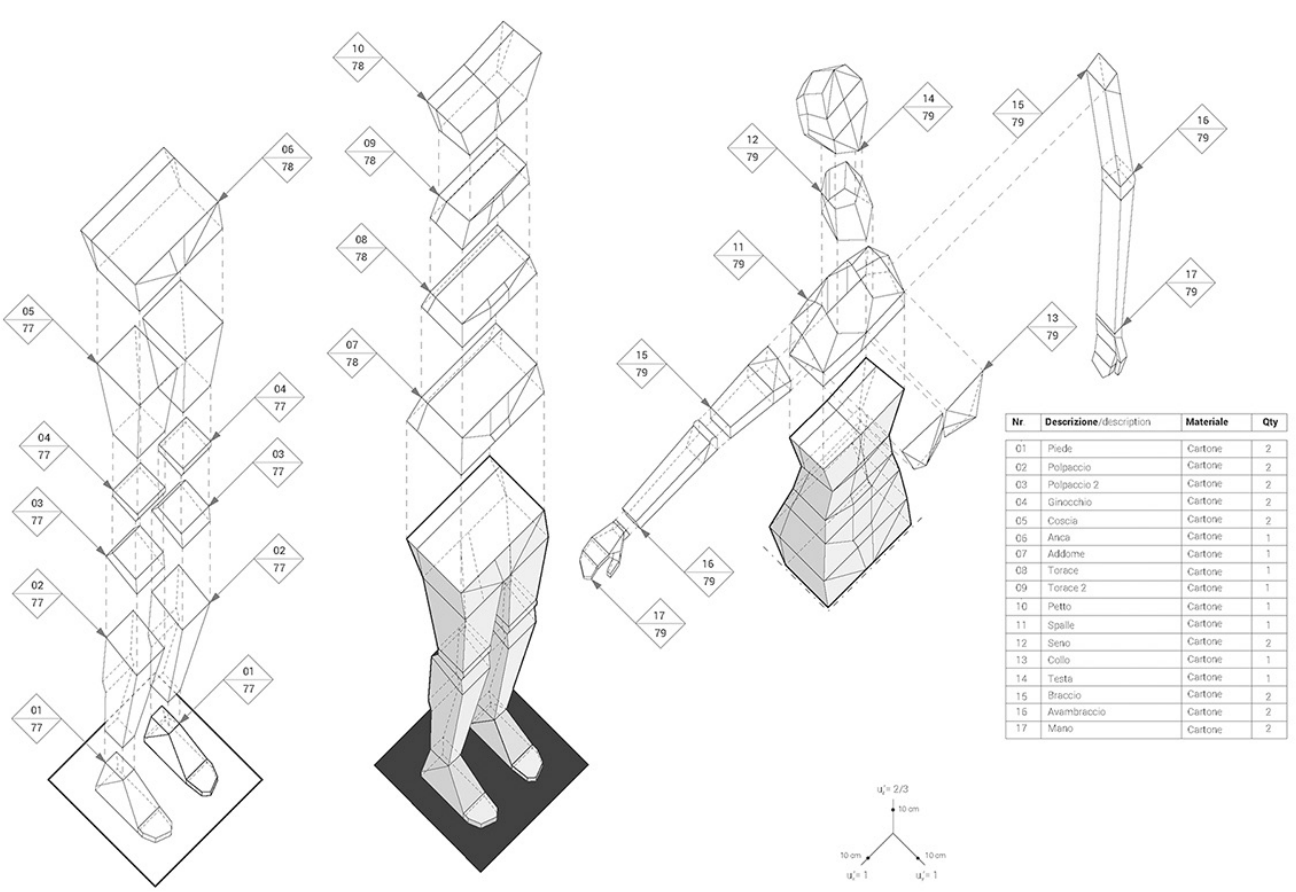
Fig. 3. Human body

sections composition

Vittorio Carlino, a.y. 20182019).

Fig. 4. Reverse engineering for the drawing and

assembly of the

components (students:

Rossi, ay 2018-2019)
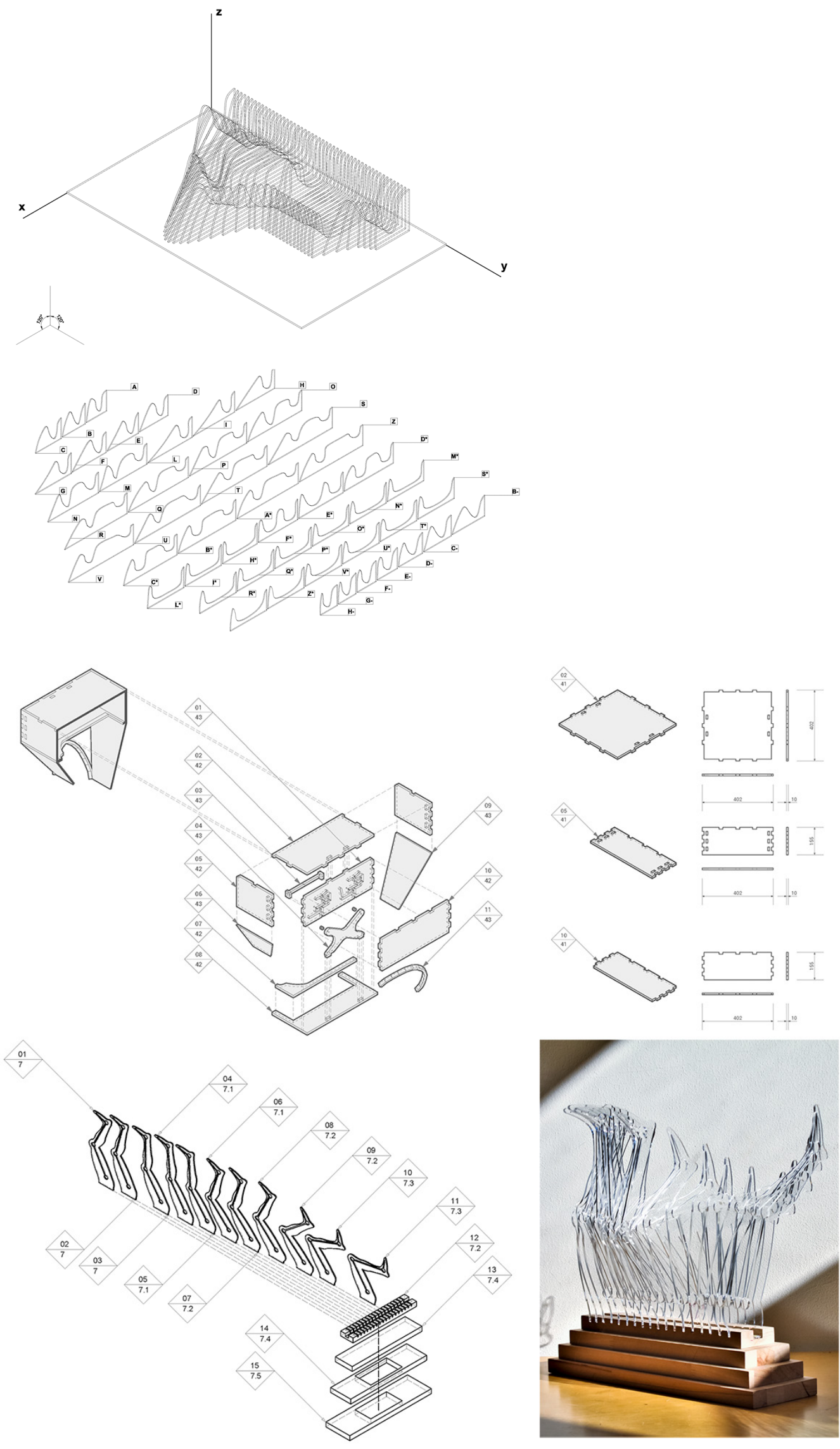


\section{From the human-body survey to bodily objects}

For the purposes of didactic and research experimentation the first object of investigation is one's own body in order to recognize oneself through different keys of interpretation. For example, proportions: understanding how each dimensional variation is proportionate. Through the Vitruvian subdivision into $8 / 8$ students were asked to critically investigate the proportional measures of their body, then comparing it with that of their partner, especially by gender comparison. Moreover, they investigated the anthropometric and postural aspects. From the point of view of both research and didactics, the research path has a dual purpose. On the one hand, the study of the proportional specificities of the human figure is tackled right from the start, and then, according to a reverse engineering approach, the rules of variation of morphology. On the other hand, through a hierarchical and selective model, the concepts of variation of form are investigated in relation to:

- gender differences in terms of growth (child, adult, elderly); ergonomic relation;

- morphological differences in relation to space (body-space, body-objects, body-furnishings); - morphological differences in relation to postural differences (postural chain) and kinesic/ dynamic differences (limb movement, flexibility, torsions).

Fig. 5. Study of the human body portion related to the project idea (student Barbara Mantovani, a.y. 2017-2018).

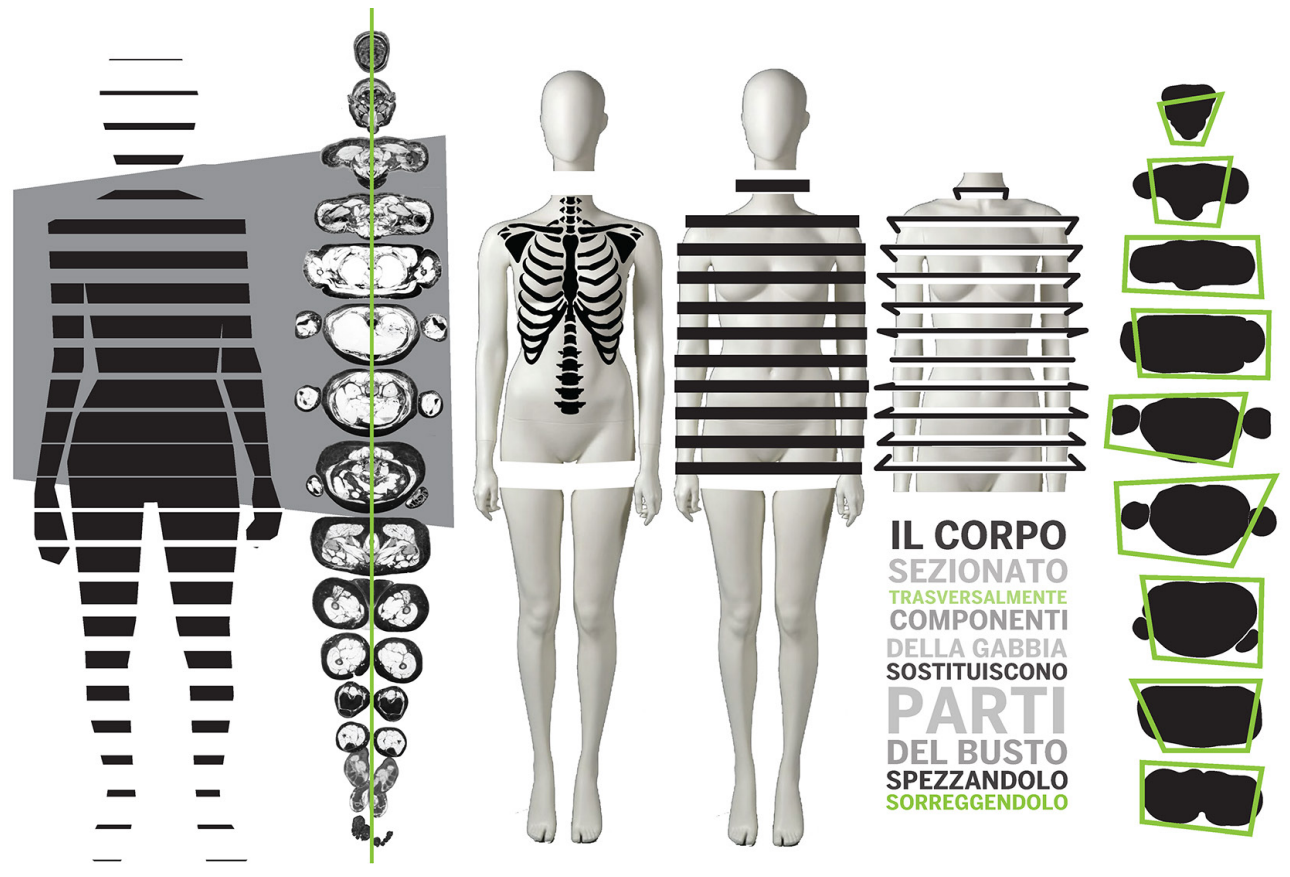

In order to proceed in the process of the investigation, a research protocol was proposed to the students, starting from the identification of planes and axes passing through known points, such as the hinges corresponding to the articulations (with relative postural chains), first examining the main spatial orientation of the body structure: upright posture and symmetrical position. Three reference planes were adopted: frontal plane; sagittal or median plane; transversal plane. The subsequent translation (using hinges and chains of the structure) of the reference planes for the identification of the representative body sections was the subject of the study of the students who, divided into groups, tackled the survey and discretized design of the human body sections in relation to an identified design theme.The theme required the definition of:

- body area: face/head/volt, neck/shoulders, forearms/hands, torso, lower limbs leg/foot;

- differences: gender, anthropometric, postural;

- movement: dynamic and kinesic interactions (actions such as sitting, leaning against a wall, overcoming an obstacle or in relation to specific functional, work or sports activities). 
Once the scope has been identified, applying the protocol in the investigation of variations and differences with respect to the reference planes, body sections are identified (and then measured and represented), elaborated according to the posture, movement and spatial dimensions of the different bodies.
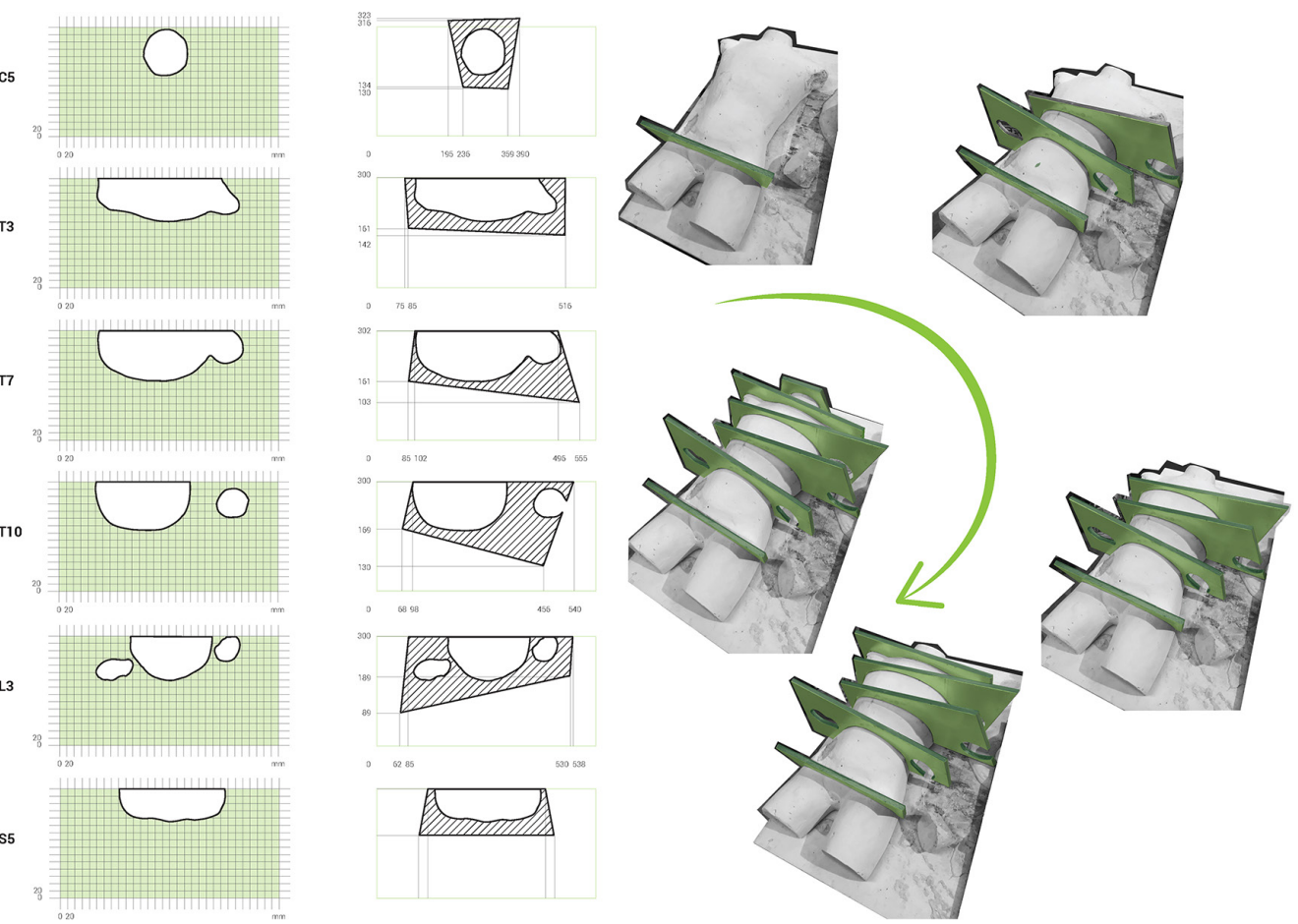

\section{From the investigation of human body to the bodily-object}

The comparison between one's own body takes place in two phases:

- the first one develops discretized volumes of the whole body of each subject. It is a body armor necessary to understand, through simple forms, the main differences and morphological and dimensional variations among the subjects of the group;

- the second phase refers to anthropometric approach in order to define a series of meta-projectural indicators used both in the subsequent representative choices of the body sections and in the composition of the final object.

The dimensions of height, length and width are measured between anthropometric reference points and in the same way the translation of the section planes takes place with reference to the same known points, in order to measure the differences about gender, anthropometric and postural characteristics. In the surveying actions we use photographic techniques on centimetric backgrounds, cardboard contact profiles and the method of orthogonal coordinates.

In this sense the concepts of ergonomics and proxemics are introduced in the survey process in order to understand, represent and develop shapes. Therefore, the research and didactics aims are the study of the relation among individuals and among space and objects in the direction of optimizing the forms related to the psychophysiological abilities and limits 
of people, but also to the meanings associated with behavior/position and the individual's way of placing himself in space and organizing it, both physically and figuratively. The process of the development of the shape of the bodily objects go through five fundamental phases: - designing of the project idea, elaborated through the technique of concept sketching;

- identifying references in art, in visual communication, in cinema, in literature, in music;

- studyong the relation with a sentiment/emotion: attributing to the body-object one or more specific affections and/or drives, not in a generic or personal sense, but using the emotional categories probed by the Hungarian philosopher Agnes Heller in her famous treatise on the Theory of Feelings [Heller 2017];

- identifying a type of kinesic/dynamic variation;

- objectification (consumerism, gender violence, exclusivity/inclusiveness).

The use of different scales is allowed to articulate objects. From the abacus of the human body components (extracted sections) are realized:

- objects that structure the bodily relationship through physical contact with one's own body: forms adherent to the body (habitable) that morphologically link the selected bodily sphere to a specific geometric-formal condition;

- furnishing objects, such as lamps, tables, shelves, which are expressions of the body relationship generated by the assembly of the sections; the motivations selected as fundamental in the application of the investigation protocol are highlighted.

The applied development process first realizes one or two prototypes and then a physical model in the laboratory with solid materials (such as wood and plexiglas), from which, with a reverse engineering approach, the final abacus and the assembly of the components in exploded axonometric is one of the main results.
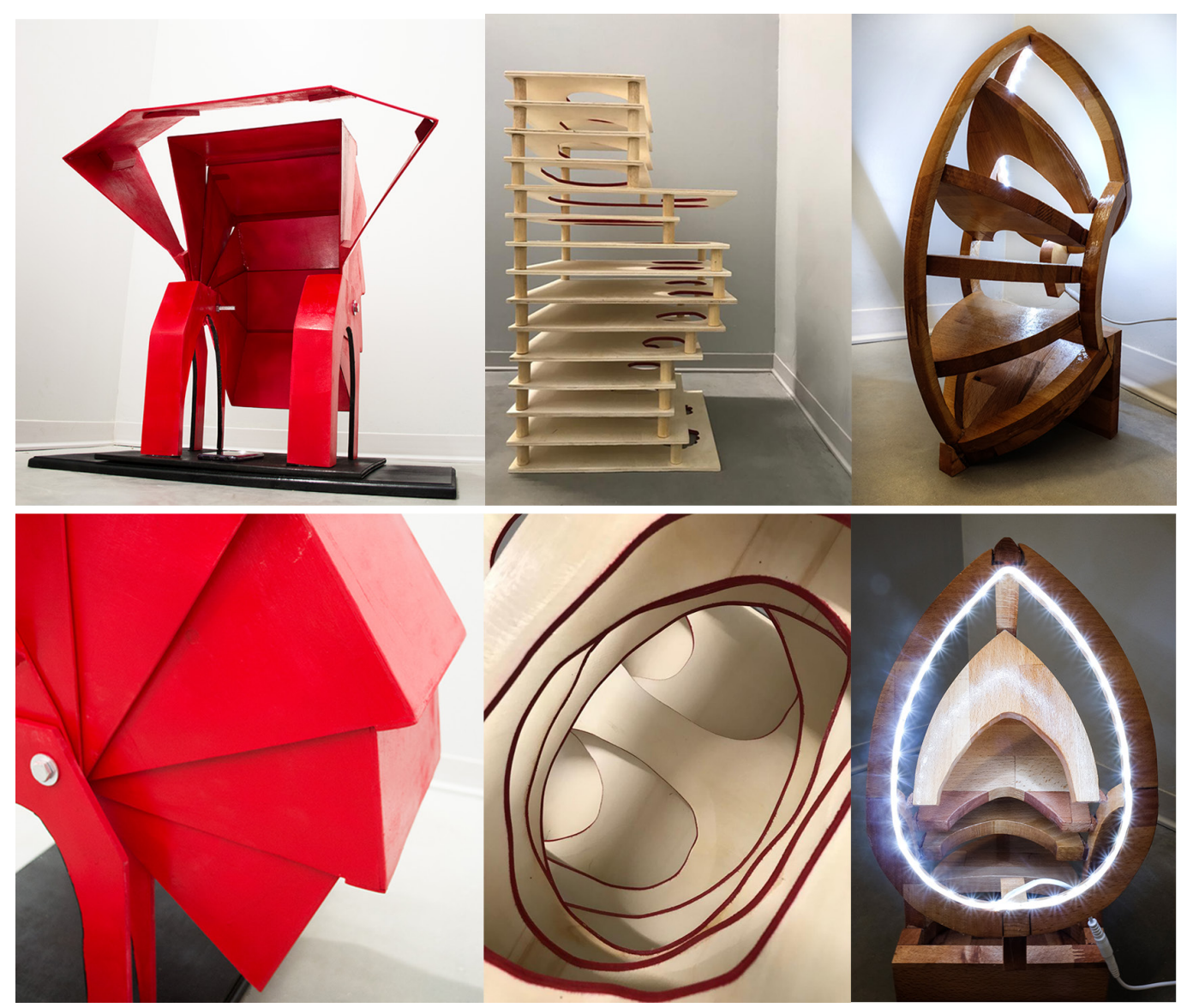


\section{Conclusions}

The research on the body dimension and on how the spatial resultant can be generated either from the geometric context of space or viceversa can be determined by the sum of all the bodily interactions (functional, energetic, postural, proxemics, emotional) in a spatial envelope that defines its apparent form is still to be completed. Moreover, the interest in the inherent conflictual relation (between human subject and confined or not confined environment) opens up areas of investigation of great interest on many interdisciplinary sides. The bodily object is basically an oxymoron in the materialization of that fluctuating signifier so dear to Lévi-Strauss, which made the body a powerful mediator between codes (today we would say domains) leveraging not only scientific but also symbolic thought. Perhaps the path defined (and briefly presented here) constitutes a useful case study of a deconstructed [Deridda 2019] combination of elements, which can, also in terms of the object result, build families of belonging, together objects of different origins, of a new formal zoology that does not lose sight of tradition and methods of relief and representation. It is thus possible to guess the development of a protocol on the body object, which is improved during the didactic experiments. It is a first research result obtained with all the authorizations (related to the use of sensitive and personal data) by the subjects interested in being both investigators and test subjects of their own body.

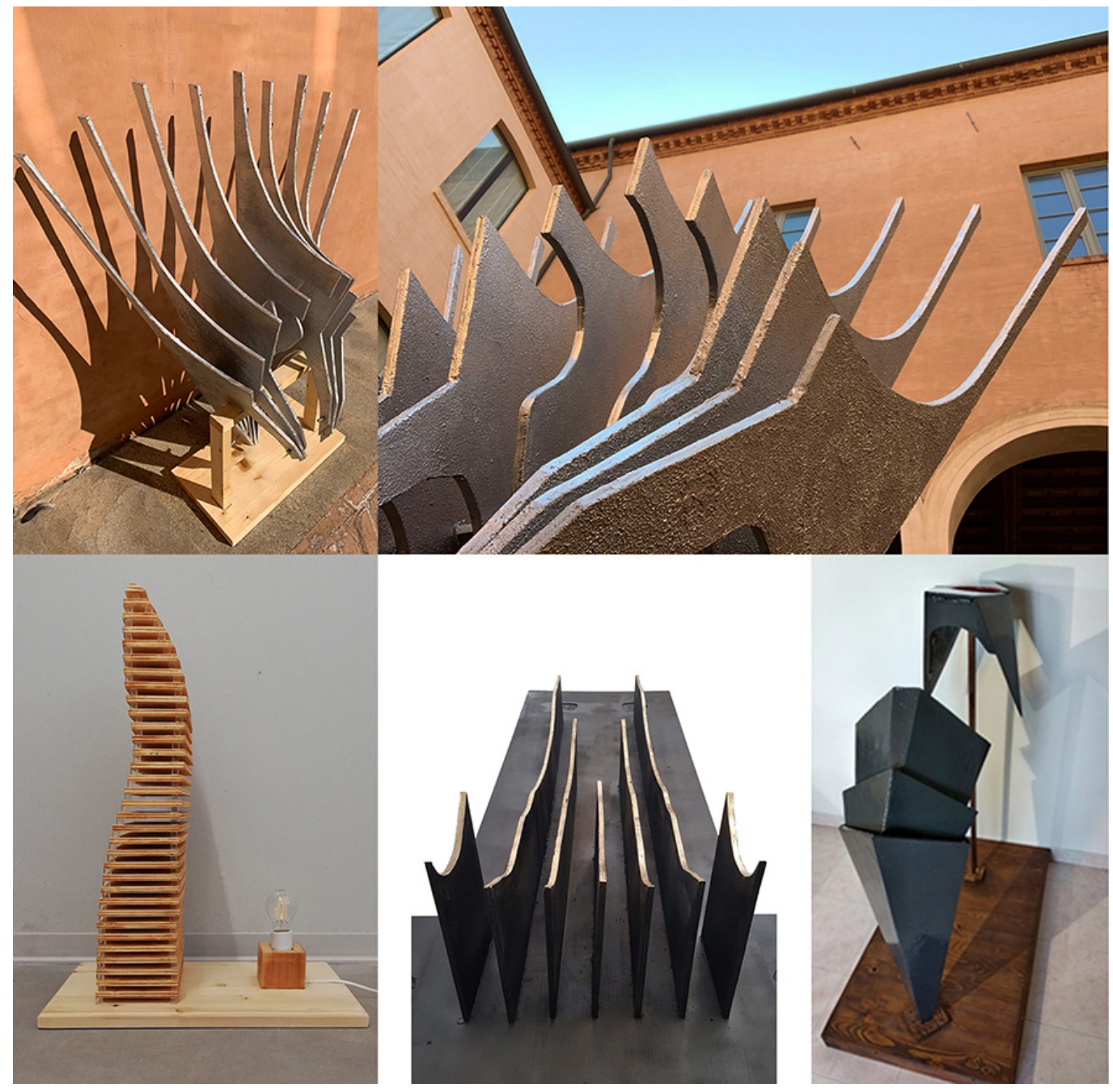




\section{References}

Adler David (2002). Manuale di dati e misure per la progettazione. Torino: Utet.

Argyle Michael (1978). Il corpo e il suo linguaggio. Bologna: Zanichelli.

Balzani Marcello et al. (2009). O3D The breaking down of the motion. The corporeal dynamism and the morphometric structures by 3D laser scanner survey. Optical 3-D Measurement Techniques IX. In AA.W. Atti del 9th Conference on Optical 3-D Measurement Techniques Optical 3-D Measurement Techniques IX.Vienna: Druckerei Janetschek, vol. I, pp. 299-305.

Boni Stefano (2014). Homo comfort. Il superamento tecnologico della fatica e le sue conseguenze. Milano: Elèuthera.

Cardone Vitale, D'Auria Saverio, De Feo Emanuela (2019). Literary and travel images for the knowledge of the city. In Janeiro Pedro António (a cura di). Atti del 5th International Seminar Architectural, Representation and other Images Drawing (...) City (...) Body, Dwelling on Earth: Imagined-Architectures: Architectural Graphic Representation and Other Images. São Paulo (Brazil), 5-9 marzo 2019, pp. 203-212. London: CRC Press, Taylor \&Francis Ltd.

Derrida Jaques (2019). Toccare, Jean-Luc Nancy. Bologna: Marietti.

Galimberti Umberto (2002). II corpo. Milano: Feltrinelli.

Gourhan André Leroi (1977). Il gesto e la parola. Tecnica e linguaggio. La memoria e i ritmi. Roma: Einaudi.

Hall Edward T. (1988). La dimensione nascosta: il significato delle distanze tra i soggetti umani. Milano: Bompiani.

Heller Agnes (2017). Teoria dei sentimenti. Roma: Castelvecchi.

Le Corbusier (1949). II modulor. Saggio su una misura armonica su scala umana universalmente applicabile all'architettura e alla meccanica. (trad. it. 1974). Milano: Mazzotta editore.

Lévi-Strauss (1962). Il totemismo oggi. Milano: Feltrinelli. (Edizione italiana 1964).

Muscogiuri Marco (2017). Disegno dal vero, urban sketching e fenomenologia della percezione. In di Luggo Antonella et al. (a cura di). Territori e frontiere della rappresentazione. Atti del $39^{\circ}$ Convegno Internazionale dei Docenti delle Discipline della Rappresentazione. Napoli, I4- 6 settembre 2017, pp. 725-732. Roma: Gangemi.

Panero Julius e Zelnik Martin (1989). Spazi a misura d'uomo: manuale delle misure utili alla progettazione. Milano: Be-Ma.

Panofsky Erwin (2010). II significato nelle arti visive. Torino: Einaudi.

Sicklinger Andreas (2009). Ergonomia applicata al progetto. Cenni Storici e Antropometria. Santarcangelo di Romagna: Maggioli Editore.

\section{Authors}

Marcello Balzani, Università degli Studi di Ferrara, bzm@unife.it

Fabiana Raco, Università degli Studi di Ferrara, rcafbn@unife.it

To cite this chapter. Balzani Marcello, Raco Fabiana (2020). L'oggetto corporeo. Lo spazio del corpo tra rilievo e rappresentazione/Object towards human body. The space of human body between the surveying and representation processes. In Arena A., Arena M., Brandolino R.G., Colistra D., Ginex G., Mediati D., Nucifora S., Raffa P. (a cura di). Connettere. Un disegno per annodare e tessere. Atti del $42^{\circ}$ Convegno Internazionale de Docenti delle Discipline della Rappresentazione/Connecting. Drawing for weaving relationships. Proceedings of the 42th International Conference of Representation Disciplines Teachers. Milano: FrancoAngeli, pp. 67-86. 